River" is by some map-makers already erroneously applied to the whole of the Hsi-chiang river. It would be as correct to call the River Ganges the "Hoogli."

\section{THE ST. PETERSBURG ACADEMY OF SCIENCE.}

$W^{E}$ have before us the yearly Report of the St. Petersburg Academy of Science, drawn up by its new secretary, Prof. A. A. Strauch ; it is full of interest, as it gives a careful analysis of the scientific work done by the Academy. After having mentioned the losses sustained by the Academy, and the new members elected, Prof. Strauch passes in review the scientific institutions connected with the Academy. The Pulkova Observatory is now under the directorship of the Moscow Professor, Th. Bredichin, well-known for his researches into the structure of comets; the Physical Observatory, under $\mathrm{H}$. Wilde, has added to its former weather warnings a system of warnings of snowstorms, which are sent to the Russian railways. A new laboratory for researches into the physiology and anatomy of plants has been opened; while the remarkable ethnographical and anthropological collections of the Academy (which contain the collections brought in by Krusenstern, Litke, Junker, Miklukho-Maclay, Polyakoff, and so on), have been lodged in a separate museum, now opened to the public. Rich collections, especially zoological, from Caucasia, Turkestan, and Mongolia, were received during the past year. Among the recent acquisitions of the library, Mr. Friedland's collection of Hebrew printed works, old and new, some of which are very rare, is especially valuable.

As to the scientific work done during the last year, the following are especially worthy of notice.

In mathematics, Prof. Ishmenetsky, continuing his researches into the functions of Bernoulli, has shown the use which may be made of them to explain the geometrical meaning of Euler's formula for the approximate calculation of surfaces limited by curves ; Prof. Markoff's work on the transformations of slowly convergent series into rapidly converging ones, and $M$. Bortkevitch's researches into the average duration of life in Russia, are also valuable contributions.

In astronomy, Prof. Backiund, besides geodetical work in the north of Russia, continued his calculations of the ephemerides of Encke's comet, which will reappear this year.

In physics, O. D. Chwolson's work upon the conductivity of metals at various temperatures is mentioned.

In meteorology, we find, besides a review of the already known publications of the Central Physical Observatory, special reference to H. Wilde's memoirs on a new (very practical) instrument of his own invention for measuring magnetical inclination, as also on his anemograph, registering pluviometer, and atmograph.

In chemistry, Prof. N. Beketoff continued his work upon the physical and chemical properties of cæsium and its oxides.

In geology, Dr. Rogon published an interesting work upon the Ganoid fishes of the Upper Silurian deposits of Oesel, as also on the Jurassic fishes of Ust-Balei in East Siberia. The six species discovered in these last deposits are intermediate forms between the Mesozoic Ganoids and the Teleostei. M. Tschersky's work is especially interesting: taking advantage of more than 2500 specimens (70 species) of fossil Mammalia discovered in Northern Siberia, he prepared a most elaborate monograph on Post-Pliocene Mammalia, which contains, first, a full account of what is already known about the Quaternary mammals in Siberia, a description of the Post Pliocene formations of Siberia generally, and their mammalian fauna, with incidental remarks upon the fauna of the caves, and, finally, a very good systematic description of 25 Post-Pliocene mammals.

In botany, the work of Prof. Maximowicz on the flora of Tibet is prominent. This flora is of high antiquity, and consists, besides its own endogenous species, of immigrants from both the Himalayas and the mountains of Mongolia. Many of those immigrants have already erolved into distinct species. Later immigrants came from China, and, later on, the Tibet flora was completed by our familiar northern plants. The orographical division of Tibet into a plateau in the west, and Alpine tracts in the East holds good for the flora as well. As to the flora of Mongolia, it is an impoverished continuation of the flora of South Siberia. Prof. Famintsyn continued his researches into the symbiosis of Algæ with Infusoria. The green grains often seen in several Infusoria proved to be Algæ having a nucleus, chromatophores, and covered with a jelly-like envelope ; their structure is identical with that of monocellular Algæ, and they multiply within Infusoria by partition. But they are incapable of an independent life, and die out soon after the death of the Infusorium they have lived in. Further research is now being carried on to ascertain in what conditions they might live independently.

In zoology, the chief work of the Academy consisted in the publication of the zoological results of Prjevalsky's expeditions. Two fascicules have now been issued containing the description of the Rodents, by E. A. Bichner, and the description of the families of Silviida, Timelizice, and Accentoride, by Th. Pleske. The chief interest of the latter fascicule is in the new genus of birds, Lophobasileus, which appears to be a connecting-link between the Sylvia and the Regulus. S. M. Hertzenstein described some new fishes from the Russian Pacific coast, and E. A. Bichner made a preliminary review of a small but very interesting zoological collection brought in by MM. Potanin and Berezovsky from the Chinese province of Kansu, and now lodged at Irkutsk. Th. Pleske issued the fourth fascicule of his "Ornithographia Rossica," which contains the description of ten Russian species of Acrocephalus.

In anatomy and physiology, Prof. Owsiannikow continued his researches into the striation of some nerves, and Dr. Tarenetski described forty-four Aino skulls from the island of Saghalien. The author is inclined to admit that they belong to a race quite different from the Mongolian.

In ethnography the Report mentions the following works :Dr. Bilenstein has terminated an important work upon the geographical distribution of the Letts, now and in the thirteenth century, in Courland and Livonia. In view of the capital interest of this work, it will be published by the Academy separately, with an atlas of maps. Prof. W. Radloff has published a facsimile of a most important document, the "Kudatku-bilik," which is the oldest representative of the Uigur language, and has, for Turkish dialects, almost the same importance as Ostromir's Gospel has for the Slavonian languages. To complete the historical and linguistic materials which will be associated with this publication, M. Radloff consulted the Eastern manuscripts of the British Museum, and is now preparing a general work upon the subject. In connection with the above, Prof. Eitling, of Strasburg, prepared for the Academy a table of Uigur, Mongol, and Mantscht alphabets, which shows that they originated from the Syrian alphabet. The likeness between Syrian and Uigur letters also permits us to guess the sounds which separate letters had in the Uigur language. Prof. Wasilieff's notes on his journey to West Siberia are also worthy of note. The learned Professor is now preparing a work on the geography of Tibet, as well as the second volume of his great work on Buddhism. Finally, M. Katanoff (of Sagai origin) visited, last year, Northern China and Turkestan, and collected a good many interesting materials relative to the Tartars, and especially the now rapidly disappearing Soyotes. His collection of tales, songs, Shaman prayers, \&c., is remarkably interesting, the more so, as all has been written down in the Soyote language (with Radloff's Turkish alphabet), and transcribed for print, on the spot, among the Sagais, who speak the Soyote language correctly.

P. K.

\section{A METHOD OF DETERMINING SPECIFIC GRAVITY.}

THE specific gravity of a single Foraminifer, such as a Globigerina, of the scales from a butterfly's wing, or of a drop of its blood, might seem a difficult task to ascertain, as indeed by the ordinary gravimetrical methods it would be plainly impossible. Yet nothing can be easier, given the following method. And to conduce to brevity we shall describe its application in a particular case, say to the spicules of the common shore sponge (Halichondria panicea). A quantity of one of the well-known heavy fluids, such as cadmium-boro-tungstate, or potassium-mercury-iodide solution, or methylene iodide, is diluted down to a density of about $2 \cdot 25$ (which is known to be above that of the spicules), and introduced into a small glass tube, about onequarter of an inch in diameter, and with two opposite flattened faces. This is cemented by one of its flat faces to an ordinary microscope slide, the axis of the tube being set at right angles to the length of the slide. ${ }^{1}$ The tube being about half-filled with heavy fluid, water (or in the case of methylene iodide, I See Proc. Roy. Dublin Soc., vol. iv. p. 374, 1885 , and Journ. R. Micr. Soc., vol. v. p. 879 . 